The Journal of Animal \& Plant Sciences, 30(5): 2020, Page: 1129-1135

ISSN (print): 1018-7081; ISSN (online): 2309-8694

\title{
SYNERGISTIC EFFECT OF DIFFERENT CONCENTRATIONS OF SODIUM CHLORIDE AND SODIUM TRIPOLYPHOSPHATE ON PHYSICOCHEMICAL PROPERTIES AND SENSORY ATTRIBUTES OF MARINATED BROILER BREAST FILLETS
}

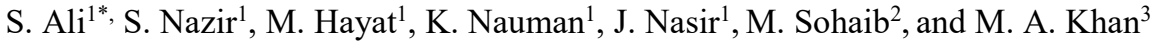 \\ ${ }^{1}$ Department of Meat Technology, Faculty of Animal Production and Technology, ${ }^{2}$ Faculty of Bio Sciences, University \\ of Veterinary and Animal Sciences, Lahore, Pakistan; ${ }^{3}$ Department of Food Science \& Technology, University College \\ of Agriculture \& Environmental Sciences, The Islamia University of Bahawalpur, Bahawalpur 63100, Pakistan. \\ Corresponding author's email : Sher.ali@uvas.edu.pk
}

\begin{abstract}
The objective of this study was to evaluate the comparative effect of combination of different concentrations of salts on quality, yield and sensory attributes of broiler breast meat. Breast fillets were vacuum tumbled for 20 minutes with $20 \%$ (based on meat weight) marinade solution. Marinade solution was made using different concentrations of sodium chloride $(\mathrm{NaCl})$ and sodium tripolyphosphate (STPP). A total of 84 breast fillets were used in this trial, and the fillets were divided into 7 groups. The $1^{\text {st }}$ group (no marination) was kept as control group $\left(\mathrm{T}_{\circ}\right), 2^{\text {nd }}$ group was treated with $3 \%$ $\mathrm{NaCl}\left(\mathrm{T}_{1}\right)$ solution in water $(\mathrm{w} / \mathrm{w}), 3^{\text {rd }}$ group was treated with $1.5 \% \mathrm{NaCl}$ and $0.3 \% \mathrm{STPP}\left(\mathrm{T}_{2}\right)$. Similarly $4^{\text {th }}, 5^{\text {th }}, 6^{\text {th }}$, and $7^{\text {th }}$ groups were treated with $1.25 \% \mathrm{NaCl}+0.35 \% \mathrm{STPP}\left(\mathrm{T}_{3}\right), 1 \% \mathrm{NaCl}+0.4 \% \mathrm{STPP}\left(\mathrm{T}_{4}\right), 0.75 \% \mathrm{NaCl}+0.45 \%$ STPP $\left(\mathrm{T}_{5}\right), 0.5 \% \mathrm{NaCl}+0.5 \%$ STPP $\left(\mathrm{T}_{6}\right)$, respectively. The $\mathrm{pH}$, color, marinade pick up and loss, cooking yield, tenderness, water holding capacity and sensory attributes were evaluated. By treating with $\mathrm{T}_{5}$ shear force values (tenderness) were improved significantly $(P \leq 0.05)$ when compared with other marination treatments and the control group. In addition, the breast fillets that were treated with $\mathrm{T}_{3}$ and $\mathrm{T}_{4}$ showed significantly $(P \leq 0.05)$ higher cooking yields and highly acceptable to the sensory panel than other treatments. Therefore, it was concluded that relatively low concentration (0.75-1.25\%) of sodium chloride in combination with low concentration (0.35-0.45\%) of sodium tripolyphosphate could improve the quality and sensory attributes of fresh vacuum tumbled poultry meat.
\end{abstract}

Key words: sodium chloride, sodium tripolyphosphate, vacuum tumbling, broiler breast meat.

https://doi.org/10.36899/JAPS.2020.5.0129

Published online June 25, 2020

\section{INTRODUCTION}

During the last few decades, poultry production, processing and consumption have increased many folds globally. The popularity of processed meat is increasing gradually due to consumer's awareness about safety and quality. Therefore, the processors are more concerned about enhancing the final yield and production efficiency of their products to improve quality and maintaining homogeneity of the products in order to improve viability in final product.

Marination is a process that apparently enhances the product value by increasing juiciness, improving flavor, tenderizing the muscle and extending the shelf life (Sheard and Tali., 2004; Latif., 2010). Efficiency of marination process can be affected by type of marinade and by technique of marination (Alvarado and Mckee., 2007). Most commonly used marinades contain water, salt, phosphate and sometimes flavoring agents and other ingredients (Smith and Acton., 2001). Sodium chloride and some type of phosphates particularly sodium tripolyphosphate are typically used to increase the tenderness, juiciness and yield of broiler breast meat
(Lyon et al., 2005; Saha et al., 2009). Previous researchers have reported that sodium chloride work synergistically with phosphate that improves the yield of whole muscle and restructured products (Kin et al., 2009). Addition of phosphates with the salts in meat product at the same time can solubilize muscular protein and this solubilized protein can bound more amount of added water (FernandezLopez et al., 2004), which ultimately improves sensory attributes.

The marination process can be performed by injection, immersion, soaking and tumbling (Gamage et al., 2017). In the processing industry, the most frequently used method of marination for poultry meat is vacuum tumbling (Bowker and Zhuang, 2017). The combination of marination and vacuum tumbling increases the tenderness of meat by terminating connections between the connective tissues and loosening the muscle structure (Smith and Young, 2007). Salt improves the tenderness, flavor and binding properties of meat so it is considered to be the most important constituent of marinade (Lorenzetti et al., 2015). However, intake of total dietary amount of salt should be less than $5 \mathrm{~g} /$ day, which is recommended by WHO (World Health Organization, 2016). The excessive use of salt in consumer's diet may 
lead to problems related to blood pressure, hypertension and increases risk of cardiovascular diseases (Desmond, 2006), so there is dire need to reduce the salt content in meat products. Due to the dietary restriction on salt intake, other ingredients like phosphates can be used in combination with salt to improve the quality of meat products. Among all phosphates, the use of sodium tripolyphosphate (STPP) is $80 \%$ in further meat processing (Mudalal et al., 2014). However, USDA limits total phosphate in the finished product to not more than $0.5 \%$.

The aim of the present study was to evaluate the comparative effect of different concentrations of sodium chloride in combination with sodium tripolyphosphate on $\mathrm{pH}$, color, water holding capacity, tenderness and sensory attributes of marinated fillets and to investigate the possible lowest concentration of salt and combinations that could be used to produce marketable broiler breasts which affect adequately on meat quality and sensory attributes.

\section{MATERIALS AND METHODS}

Sample preparation: A total of 84 breast fillets with an everage weight of $130 \mathrm{~g} \pm 10 \mathrm{~g}$ were purchased from the retail market and transported in ice box at $4{ }^{\circ} \mathrm{C}$ until arrival at the Department of Meat Science and Technology, UVAS, Lahore-Pakistan. Samples were divided into 7 groups (12 samples per group), tagged and marinated within 24 hours. Marination treatments were consisted of 6 batches of broiler breast fillets that were vacuum tumbled for 20 minutes with $20 \%$ marinade solution (based on meat weight). Marinade solution was made by using different concentrations of sodium chloride $(\mathrm{NaCl})$ and sodium tripolyphosphate (STPP). The first group was kept as control group and was not marinated with sodium chloride or sodium tripolyphosphate, $2^{\text {nd }}$ group was treated with $3 \% \mathrm{NaCl}$, $3^{\text {rd }}$ group was treated with $1.5 \% \mathrm{NaCl}$ and $0.3 \%$ STPP. Similarly $4^{\text {th }}, 5^{\text {th }}, 6^{\text {th }}$, and $7^{\text {th }}$ groups were treated with $1.25 \% \mathrm{NaCl}+0.35 \%$ STPP, $1 \% \mathrm{NaCl}+0.4 \%$ STPP, $0.75 \% \mathrm{NaCl}+0.45 \%$ STPP, $0.5 \% \mathrm{NaCl}+0.5 \%$ STPP, respectively. After each treatment, the vacuum tumbler was cleaned, washed with water, and cooled to $4^{\circ} \mathrm{C}$. After marination, the breast fillets were packed in polystyrene food grade trays, wrapped with cling film and placed in chiller operating at $0-4^{\circ} \mathrm{C}$ for further evaluation.

Marinade uptake (\%): To calculate the marinade uptake, the breast fillets were tumbled in a vacuum tumbler. Marinade uptake was calculated by measuring the difference between initial and final weight of the breast fillets (Yusop et al., 2010).

Marinade uptake percentage was calculated by using the following formula:

Marinade uptake $(\%)=\frac{w 2-w 1}{w 1} \times 100$
Where,

$\mathrm{W} 1=$ weight of breast fillets before marination

$\mathrm{W} 2=$ weight of breast fillets after marination

Marinade loss (\%): Marinated breast fillets were stored in chiller operating at $0-4{ }^{\circ} \mathrm{C}$ and reweighed after 24 hours of tumbling to calculate the marinade retention percentage. Marinade retention percentage was calculated following formula:

Marinade loss $(\%)=\frac{w 2-w 3}{w 2} \times 100$

Where,

$\mathrm{W} 2=$ weight of breast fillets after marination

W3 = weight of breast fillets after 24 hours stored

pH: Instrumental pH measurements were taken after 24 hours of marination by using a $\mathrm{pH}$ meter (WTW, $\mathrm{pH}$ 3210 SET 2, Germany). The $\mathrm{pH}$ was measured from pectorals major muscle with the help of meat penetrating probe. The $\mathrm{pH}$ was measured by inserting the penetrating probe into the center of the thickest part of pectorals major muscle (Yusop et al., 2010).

Color: Color values of the breast fillets were measured by using colorimeter (Konica Minolta ${ }^{\circledR}$ CR-410, Japan) after 24 hours of marination. After calibrating the calorimeter by Minolta calibration plate, three consecutive readings from the topside of the breast fillets were measured.

Warner-bratzler shear force value: Tenderness was measured from the breast fillets that were used for the determination of cooking loss. From each cooked fillet, five samples of approximately $1 \mathrm{~cm}^{2}$ were obtained by cutting along the parallel axis to the muscle fiber orientation using scalpel blade. Then the warner-bratzler shear force values $\left(\mathrm{N} / \mathrm{cm}^{2}\right)$ were measured with the help of Texture analyzer (TA.XT plus ${ }^{\circledR}$ texture analyzer, UK) by placing the cubes at right angle to blade surface.

Cooking loss (\%): For the measurement of cooking loss the samples were weighed and vacuum packed by using vacuum packing machine (MULTIVAC®) Baseline $\mathrm{P} 100)$. Then the samples were placed in water bath (Memmert WNB45, Germany) operating at $80^{\circ} \mathrm{C}$ until breast fillets attained a core temperature of $72^{\circ} \mathrm{C}$. Temperature of the samples was determined by using a food grade digital thermometer (TP101; temperature range $-50^{\circ} \mathrm{C}$ to $300^{\circ} \mathrm{C}$ ). It took approximately 30 minutes to attain the core temperature of $72^{\circ} \mathrm{C}$. After cooking, the breast fillets were placed in food grade polystyrene trays, which were warped by cling film and cooled down in horizontal display chiller (ALVO, Model MD-12) working at $0-4^{\circ} \mathrm{C}$, until they attained room temperature. Cooked fillets were weighed again to determine the cooking loss. Cooking loss percentage was calculated through the formula given below

Cooking loss $(\%)=\frac{w 1-w 2}{w 1} \times 100$ 
Where,

$\mathrm{W} 1=$ weight of breast fillets before cooking

$\mathrm{W} 2=$ weight of breast fillets after cooking

Expressible moisture: Water holding capacity was measured by compression method (Li et al., 2012) with the help of compression machine (YYW-2, Nanjing Soil Instrument, and Nanjing, China). A raw meat sample of 5 $\mathrm{g}$ was placed between 18 pre-weighed Whatman (No.1) filter papers and pressed under a force of $343 \mathrm{~N}$ for 5 minutes. Pressing loss was measured by following formula:

Expressible water $(\%)=\frac{w 1-w 2}{w 1} \times 100$

Where,

$\mathrm{W} 1=$ Initial weight of breast fillets

$\mathrm{W} 2=$ Final weight of breast fillets

Sensory analysis: Sensory evaluation was performed in sensory analysis lab at Central Laboratory Complex (CLC), UVAS by expert taste panel. The method used reference scales to assess intensity of characteristics parameters for intensity points. For the testing sessions, the characteristics were evaluated using a 1 to 9 point category scale $(9=$ excellent juiceness uniformity/extremely good flavor/extremely acceptable; 1 $=$ very poor juiceness /very poor flavor/not acceptable). Chicken breast fillet samples from each treatment were baked under the same conditions and specimens were further subdivided into equal parts and served to all member of the sensory panel. All samples were tagged and served warm, and amongst all the samples, the panelist had the facility to rinse thier mouth to rinse all carry over effect. The sensory evaluation was done by an experienced sixteen members trained panel (10 Males: 6 Females) with an age group of 32 to 45 years. The panel evaluated the samples for odor, tenderness, juiciness, flavor and overall acceptability sensory parameter on 9 points hedonic scale (Saha et al., 2009).

Statistical analysis: Collected data was analyzed through one-way ANOVA technique using PROC GLM in SAS (version 9.1) software. Significant treatment means were separated through Duncan's Multiple Range test at $\mathrm{P} \leq$ 0.05 probability level. Different concentrations of sodium chloride and sodium tripolyphosphate were defined as the main effect to determine the synergistic influence of salt and STPP on meat quality attributes.

Following mathematical model was used:

$\mathrm{Y}_{\mathrm{ijk}}=\mu+\mathrm{T}_{\mathrm{i}}+\varepsilon_{\mathrm{ijk}}$

Where,

$Y_{i j k}=j^{\text {th }}$ observation of dependent variable recorded on $i^{\text {th }}$ treatment

$\mu=$ Population Mean

$T_{i}=$ Effect of $i^{\text {th }}$ treatment $(i=1,2,3,4,5,6,7)$

$\varepsilon_{\mathrm{ijk}}=$ Random error associated with $\mathrm{j}^{\text {th }}$ observation on $\mathrm{i}^{\text {th }}$ treatment, NID $\sim 0, \sigma 2$

\section{RESULTS AND DISCUSSION}

Marinade uptake: In the present study, significant differences $(P \leq 0.05)$ were observed among different marination treatments with respect to marinade uptake percentage (Table 1). The treatment $T_{1}$ exhibited lowest marinade pickup when compared with other marination treatments. Treatment $\mathrm{T}_{3}$ showed the highest marinade pickup and it was statistically similar to treatments $T_{2}$ and $\mathrm{T}_{4}$. The difference in marinade pickup is due to presence of $\mathrm{NaCl}$ alone and absence of STTP in treatment $\mathrm{T}_{1}$. Because salt can only enhance the swelling of protein structure by electrostatic repulsive forces, but in combination with phosphate, it can also extract salt soluble proteins of meat and as a result marinade absorption and retention enhanced during further processing and storage (Smith and Acton, 2001). The results of present study was similar to the study of Young and Smith, (2004), who reported that marinade uptake of chicken breast fillets increased by marinating with solution of $\mathrm{NaCl}$ and STPP under vacuum pressure. Similarly, Gorsuch and Alvarado, (2010) reported that marinade pickup of broiler breast fillets was improved by marinating with low concentrations of salt and phosphate. They concluded that marination pickup of broiler breast fillets was $17.7 \%$ when marinated with the combination of sodium chloride and sodium tripolyphosphate.

Marinade loss: Results of the present study showed significant differences $(P \leq 0.05)$ among different marination treatments with respect to marinade loss percentage (Table 1). The treatment $\mathrm{T}_{4}$ showed minimum marinade loss while the treatment $T_{1}$ showed highest marinade loss as compared to other marination treatments. This highest loss was due to the presence of salt alone in the marination solution. Because salt alone can increase the ionic strength to bind more water but cannot alter $\mathrm{pH}$, on the other hand phosphate can increase the water holding capacity by muscle protein extraction and by shifting the $\mathrm{pH}$ of muscle away from isoelectric point (Puolanne et al., 2001; Young et al., 2005). Therefore, the addition of phosphates with the salts in meat product at the same time can solubilize muscular protein and this solubilized protein can bind more amount of added water (Fernandez-Lopez et al., 2004). The result of present study was similar to the study of Gorsuch and Alvarado, (2010), who reported that marinade pickup and retention of broiler breast fillets improved by marinating with the sodium chloride and sodium tripolyphosphate.

pH: In the present study, the $\mathrm{pH}$ values of broiler breast fillets were significantly different $(P \leq 0.05)$ among different marinated treatments and control group (Table1). All marinated treatments $\left(T_{2}-T_{6}\right)$ except $T_{1}$ showed higher $\mathrm{pH}$ values because of the presence of different concentrations of sodium tripolyphosphate. The treatments $\mathrm{T}_{\circ}$ (control) and $\mathrm{T}_{1}(3 \% \mathrm{NaCl})$ showed 
relatively lower $\mathrm{pH}$ value because of absence of sodium tripolyphosphate. However, treatment $T_{2}$ had significant increase in $\mathrm{pH}$ when compared with $\mathrm{T}_{\circ}$ and $\mathrm{T}_{1}$ and this increase in $\mathrm{pH}$ was continued all the way to $\mathrm{T}_{6}$. Sodium tripolyphosphate is alkaline in nature and its addition to meat and meat products increases the water holding capacity due to muscle protein extraction and by shifting the $\mathrm{pH}$ of muscle away from isoelectric point (Puolanne et al., 2001; Young et al., 2005). In addition, these results were comparable to the results described by Woelfel and Sams, (2001), who reported in their study that the $\mathrm{pH}$ values were increased after marination, when marination solution of $\mathrm{pH} 9$ was used.

Color: Color analysis results are shown in Table 2. Chicken breast meat lightness $\left(\mathrm{L}^{*}\right)$ values of marinated groups were significantly different $(P \leq 0.05)$ from control group (Table 2). The control group showed higher lightness $\left(L^{*}\right)$ value then the marinated groups. However treatment (T2) showed lowest $\left(\mathrm{L}^{*}\right)$ value and (T6) showed highest $\left(\mathrm{L}^{*}\right)$ value as compared to control group. Meawhile, the fillets that were treated with $T_{2}$ showed optimum color $\left(\mathrm{L}^{*}, \mathrm{a}^{*}, \mathrm{~b}^{*}\right)$ values. Because addition of salt to the meat leads to increase in ionic strength which improve the water binding capability of protein, this increase in water holding capacity reduces the availability of water on the surface of meat resulting in less visual lightness (Ruusunen and Puolanne, 2005). Similarly, phosphate also improves the water holding capacity by affecting the isoelectric points of protein and results into less light reflection and lightness values (FernandezLopez et al., 2004). However, the color values of redness $\left(\mathrm{a}^{*}\right)$ were unable to show any significant results $(P>$ $0.05)$. The redness $\left(\mathrm{a}^{*}\right)$ values were similar in all marinated groups, as well as in control group. Yellowness was lowest $(P \leq 0.05)$ in (T1) and the highest in (T5) marinated fillets as compared to the control group. These results were fairly similar to the study of Lopez et al., (2012), who reported that after marintaion with low concentrations of salt and phosphate, the ligtness and yellownes values of broiler breast fillets were decreasd by increasing the concentration of salt, while the redness value remain non significant.

Cooking yield: Cooking yield \% values of marinated and non-marinated breast fillets were significantly different $(P \leq 0.05)$. The fillets that were treated with different combinations of sodium chloride and sodium tripolyphosphate showed significantly higher cooking yield when compared with non-marinated fillets and those fillets that were marinated with $\mathrm{NaCl}$ alone (Table $3)$. As the $\mathrm{NaCl}$ alone can only provide ionic strength while phosphate solubilizes much protein and form a layer of coagulate protein on the surface of meat that leads to decrease water loss and result into higher yields (Lopez et al., 2012; Lorenzetti et al., 2015). In this trail, the treatment $\mathrm{T}_{3}$ showed higher cooking yield which was significantly similar to $T_{2}$ and $T_{4}$. These results were similar to Smith and Young, (2007), in their study they reported that the cooking yield of broiler breast fillets was increased from $76.6 \%$ to $86.1 \%$ when marinated with the combination of STPP and NaCl. Similarly, (Carroll et al. (2007) compared different marinating treatments, they reported that combination of $\mathrm{NaCl}(1.5 \%)$ and STPP $(0.45 \%)$ showed minimum cooking loss $(14.1 \%)$. In addition, Alvarado and Sams, (2004) revealed that vacuum tumbling with a sodium chloride and sodium tripolyphosphate increase the cooking yield of broiler breast fillets. In another study, Kin et al. (2009) reported that the combine utilization of $\mathrm{NaCl}$ and phosphates enhanced yield in restructured products and whole muscle.

Expressible moisture: The escape of free water from protein system of meat after application of force is known as expressible moisture (Park et al., 2000). In this study, the broiler breast fillets that were treated with different concentration of salt and sodium tripolyphosphate had significantly $(P \leq 0.05)$ less expressible moisture as compared to untreated fillets (Table 3). All the treatments showed similar expressible moisture irrespective of level of $\mathrm{NaCl}$ and STPP added in the solution, this representing that the addition of $\mathrm{NaCl}$ and STPP improved the water holding capacity but the amount of $\mathrm{NaCl}$ and STPP had minimal effect on expressible moisture. These results were similar to the study of Lopez et al., (2012), in their study they reported that the expressible moisture was lower in the fillets that were marinated with different concentratios of salt and phosphate when compared with non marinated fillets. Similarly Komoltri and Pakdeechanuan, (2012) compared different combinations of marinating ingredients and reported that the breasts marinated with $\mathrm{NaCl}$ and STPP showed higher water holding capacity than non marinated breasts. In another study Froning and Sackett, (1985), they reported that the water holding capacity of turkey breast fillets increased by marinating with sodium chloride and phosphate solution.

Warner-bratzler shear force value: Warner-bratzler revealed significant differences $(P \leq 0.05)$ among marinated and non-marinated breast fillets for shear force values (Table 3 ). The breast fillets that were marinated with different combinations of salt and sodium tripolyphosphate showed lower shear force values when compared with non-marinated breast fillets. However, those fillets that were treated with salt alone had higher shear force values when compared with other marinated treatments $\left(T_{2}-T_{5}\right)$. Basically salt works synergistically with phosphate to improve the tenderness and yield of whole muscle and restructured products (Kin et al., 2009). Salts can enhance the swelling of protein structure but they do not solubilize that proteins. On the other hand phosphate can remove the link between myosin and actin 
(Long et al., 2011). Therefore, the non-marinated fillets and the fillets that were treated with $\mathrm{NaCl}$ alone had higher shear force values when compared with the fillets that were treated with different combinations of salt and phosphate. The treatment $\mathrm{T}_{5}$ showed minimum shear force value $(11.43 \mathrm{~N})$ followed by $\mathrm{T}_{4}(11.78 \mathrm{~N})$ and $\mathrm{T}_{3}$ $(11.93 \mathrm{~N})$. These results were similar to the study of (Lopez et al., 2012), in their study they decsribed that marinades comprising of low concentrations of $\mathrm{NaCl}$ and STPP can enhance the tenderness of broiler breast fillets. In addition, Saha et al.(2009) described that the tenderness of broiler breast was improved by marinating with the combination of salt and sodium tripolyphosphate. Similarly, Maki and Froning (1987) reported that the turkey breasts injected with phosphates and after that tumbled without vacuum had lesser shear force values than that of non-injected samples. Moreover, in another study Komoltri and Pakdeechanuan (2012) reported that the shear force values of chicken breast fillets marinated with $5 \% \mathrm{NaCl}$ and 1\% STPP were considerably lesser than those of non-marinated breast fillets and the breast fillets soaked in distilled water.

Sensory evaluation: Sensory evaluation is a subjective method of determining the quality of meat by the use of final comprehensive scores. Results based on the responses of the panelists, there were significant $(P \leq$ 0.05 ) differences in the values of odor, texture, juiciness, flavor and overall acceptability among marinated and non-marinated boiler breast samples (Table 4). Marinated breast fillets performed better than non marinated breast fillets. For all sensory attributes, the scores from the breast fillets that were marinated with different concentrations of salt and phosphate were higher when compared with the fillets that were not treated with any salt and phosphate. The fillets that were treated with $T_{1}$ showed high odor score, this is because the protein receptors of meat bind with the sodium in salt and enhance the aroma of the meat by changing the osmotic pressure. This change in osmotic pressure cause volatile aromatic compounds less soluble within the meat thus enhancing the aroma (Lopez et al., 2012). However, treatment $\mathrm{T}_{4}$ showed high juiciness, texture and overall acceptability scores when compared with other treatments. This is due to presence of salt in combination with phosphate, because salt alone can only increase ionic strength while phosphate solubilizes much protein and form a layer of coagulated proteins on the surface of meat that leads to decrease water loss during cooking and yields more juicy product (Lopez et al., 2012; Lorenzetti et al., 2015). Similarly salt can enhance the swelling of protein structure but they do not solubilize that proteins on the other hand phosphate can remove the link between myosin and actin and provide tender meat after cooking (Long et al., 2011). These results were similar to the study of Saha et al. (2009), who reported greater consumer acceptance when breast fillets were treated with different concentrations of salt and phosphates when compared with non-marinated breast fillets.

Table 1. Marinade pickup \%, marinade loss \% and pH (Mean $\pm{ }^{3} \mathrm{SE}$ ) of broiler breast fillets that were marinated with salt and phosphate.

\begin{tabular}{|c|c|c|c|c|}
\hline \multicolumn{2}{|c|}{ Treatments } & Marinade uptake (\%) & Marinade loss (\%) & pH \\
\hline $\mathrm{T}_{\circ}$ & Control & $\mathrm{N} / \mathrm{A}$ & $\mathrm{N} / \mathrm{A}$ & $5.71^{\mathrm{c}} \pm 0.02$ \\
\hline $\mathrm{T}_{1}$ & $3 \%{ }^{1} \mathrm{NaCl}$ & $15.05^{\mathrm{c}} \pm 0.21$ & $3.66^{\mathrm{a}} \pm 0.32$ & $5.75^{\mathrm{c}} \pm 0.03$ \\
\hline $\mathrm{T}_{2}$ & $1.5 \% \mathrm{NaCl}+0.3 \%{ }^{2} \mathrm{STPP}$ & $17.81^{\mathrm{a}} \pm 0.33$ & $2.95^{\mathrm{bcd}} \pm 0.04$ & $5.83^{\mathrm{b}} \pm 0.01$ \\
\hline $\mathrm{T}_{3}$ & $1.25 \% \mathrm{NaCl}+0.35 \%$ STPP & $17.95^{\mathrm{a}} \pm 0.33$ & $3.19^{b c} \pm 0.06$ & $5.83^{\mathrm{ab}} \pm 0.02$ \\
\hline $\mathrm{T}_{4}$ & $1 \% \mathrm{NaCl}+0.4 \% \mathrm{STPP}$ & $17.73^{\mathrm{a}} \pm 0.23$ & $2.62^{\mathrm{d}} \pm 0.09$ & $5.85^{\mathrm{ab}} \pm 0.00$ \\
\hline $\mathrm{T}_{5}$ & $0.75 \% \mathrm{NaCl}+0.45 \%$ STPP & $17.54^{\mathrm{a}} \pm 0.27$ & $2.75^{\mathrm{cd}} \pm 0.11$ & $5.86^{\mathrm{ab}} \pm 0.00$ \\
\hline $\mathrm{T}_{6}$ & $0.5 \% \mathrm{NaCl}+0.5 \% \mathrm{STPP}$ & $16.02^{\mathrm{b}} \pm 0.25$ & $3.39^{\mathrm{ab}} \pm 0.04$ & $5.88^{\mathrm{a}} \pm 0.02$ \\
\hline \multicolumn{2}{|c|}{ P-value } & $\leq .0001$ & 0.0002 & $\leq .0001$ \\
\hline
\end{tabular}

Different alphabets on means showing significant differences within a raw $(P \leq 0.05)$.

${ }^{1}$ Sodium chloride

${ }^{2}$ Sodium tripolyphosphate

${ }^{3}$ Standard error

Table 2. Surface color (Mean \pm SE) of broiler breast fillets that were marinated with salt and phosphate.

\begin{tabular}{llcrc}
\hline \multicolumn{2}{c}{ Treatments } & L $^{*}$ (lightness) & a $^{*}$ (redness) & b $^{*}$ (yellowness) \\
\hline $\mathrm{T}_{\circ}$ & Control & $61.18^{\mathrm{a}} \pm 0.43$ & $13.27 \pm 0.21$ & $16.06^{\mathrm{a}} \pm 0.14$ \\
$\mathrm{~T}_{1}$ & $3 \%{ }^{1} \mathrm{NaCl}$ & $54.79^{\mathrm{ef}} \pm 0.35$ & $13.71 \pm 0.36$ & $13.60^{\mathrm{d}} \pm 0.16$ \\
$\mathrm{~T}_{2}$ & $1.5 \% \mathrm{NaCl}+0.3 \%{ }^{2} \mathrm{STPP}$ & $54.16^{\mathrm{f}} \pm 0.29$ & $13.34 \pm 0.12$ & $14.06^{\mathrm{bcd}} \pm 0.22$ \\
$\mathrm{~T}_{3}$ & $1.25 \% \mathrm{NaCl}+0.35 \% \mathrm{STPP}$ & $55.08^{\mathrm{e}} \pm 0.34$ & $13.28 \pm 0.24$ & $13.68^{\mathrm{d}} \pm 0.17$ \\
$\mathrm{~T}_{4}$ & $1 \% \mathrm{NaCl}+0.4 \% \mathrm{STPP}$ & $56.12^{\mathrm{d}} \pm 0.28$ & $13.55 \pm 0.21$ & $13.88^{\mathrm{cd}} \pm 0.08$ \\
$\mathrm{~T}_{5}$ & $0.75 \% \mathrm{NaCl}+0.45 \% \mathrm{STPP}$ & $57.19^{\mathrm{c}} \pm 0.17$ & $13.69 \pm 0.45$ & $14.41^{\mathrm{b}} \pm 0.12$
\end{tabular}




\begin{tabular}{|c|c|c|}
\hline $\mathrm{T}_{6} \underset{P \text {-value }}{0.5 \% \mathrm{NaCl}+0.5 \% \mathrm{STPP}}$ & $\begin{array}{c}59.02^{\mathrm{b}} \pm 0.10 \\
\leq .0001\end{array}$ & $\begin{array}{c}14.32^{\mathrm{bc}_{ \pm}} \leq 0.13 \\
\leq .0001\end{array}$ \\
\hline $\begin{array}{l}\text { Different alphabets on means showing } \\
{ }^{1} \text { Sodium chloride } \\
{ }^{2} \text { Sodium tripolyphosphate }\end{array}$ & ces within a raw $(P \leq 0.05)$. & \\
\hline
\end{tabular}

\begin{tabular}{llccc}
\hline \multicolumn{1}{c}{ Treatments } & Cooking yield (\%) & $\begin{array}{c}\text { Expressible moisture } \\
(\mathbf{\%})\end{array}$ & ${ }^{3} \mathbf{W B S F}\left(\mathbf{N} / \mathbf{c m}^{\mathbf{2}}\right)$ \\
\hline $\mathrm{T}_{\circ}$ & Control & $76.93^{\mathrm{c}} \pm 0.24$ & $16.19^{\mathrm{a}} \pm 0.49$ & $17.70^{\mathrm{a}} \pm 0.13$ \\
$\mathrm{~T}_{1}$ & $3 \%{ }^{1} \mathrm{NaCl}$ & $86.84^{\mathrm{b}} \pm 0.32$ & $14.78^{\mathrm{b}} \pm 0.18$ & $12.18^{\mathrm{c}} \pm 0.10$ \\
$\mathrm{~T}_{2}$ & $1.5 \% \mathrm{NaCl}+0.3 \%{ }^{2} \mathrm{STPP}$ & $89.52^{\mathrm{a}} \pm 0.34$ & $14.36^{\mathrm{b}} \pm 0.27$ & $12.13^{\mathrm{c}} \pm 0.11$ \\
$\mathrm{~T}_{3}$ & $1.25 \% \mathrm{NaCl}+0.35 \% \mathrm{STPP}$ & $89.71^{\mathrm{a}} \pm 0.42$ & $13.91^{\mathrm{b}} \pm 0.27$ & $11.93^{\mathrm{c}} \pm 0.10$ \\
$\mathrm{~T}_{4}$ & $1 \% \mathrm{NaCl}+0.4 \% \mathrm{STPP}$ & $89.65^{\mathrm{a}} \pm 0.26$ & $13.80^{\mathrm{b}} \pm 0.46$ & $11.78^{\mathrm{d}} \pm 0.08$ \\
$\mathrm{~T}_{5}$ & $0.75 \% \mathrm{NaCl}+0.45 \% \mathrm{STPP}$ & $87.11^{\mathrm{b}} \pm 0.28$ & $13.79^{\mathrm{b}} \pm 0.46$ & $11.43^{\mathrm{e}} \pm 0.08$ \\
$\mathrm{~T}_{6}$ & $0.5 \% \mathrm{NaCl}+0.5 \% \mathrm{STPP}$ & $84.88^{\mathrm{c}} \pm 0.30$ & $14.56^{\mathrm{b}} \pm 0.20$ & $12.77^{\mathrm{b}} \pm 0.05$ \\
\multicolumn{2}{c}{$P$-value } & $\leq .0001$ & 0.0003 & $\leq .0001$ \\
\hline
\end{tabular}

Different alphabets on means showing significant differences within a raw $(P \leq 0.05)$.

${ }^{1}$ Sodium chloride

${ }^{2}$ Sodium tripolyphosphate

${ }^{3}$ Warner Bratzler Share Force $\left(\mathrm{N} / \mathrm{cm}^{2}\right)$

Table 4. Sensory attributes (Mean $\pm^{3} \mathrm{SE}$ ) of broiler breast fillets that were marinated with salt and phosphate.

\begin{tabular}{|c|c|c|c|c|c|c|}
\hline \multicolumn{2}{|r|}{ Treatments } & Odor & Texture & Juiciness & Flavor & $\begin{array}{c}\text { Overall } \\
\text { acceptability }\end{array}$ \\
\hline $\mathrm{T}_{\circ}$ & Control & $5.17^{\mathrm{e}} \pm 0.17$ & $5.17^{\mathrm{c}} \pm 0.79$ & $5.00^{\mathrm{e}} \pm 0.00$ & $4.33^{c} \pm 0.21$ & $4.83^{\mathrm{d}} \pm 0.17$ \\
\hline $\mathrm{T}_{1}$ & $3 \%{ }^{1} \mathrm{NaCl}$ & $7.83^{\mathrm{a}} \pm 0.17$ & $7.50^{\mathrm{ab}} \pm 0.43$ & $7.67^{b} \pm 0.21$ & $7.67^{\mathrm{ab}} \pm 0.33$ & $7.67^{\mathrm{ab}} \pm 0.21$ \\
\hline $\mathrm{T}_{2}$ & $1.5 \% \mathrm{NaCl}+0.3 \%{ }^{2} \mathrm{STPP}$ & $7.50^{\mathrm{ab}} \pm 0.22$ & $7.83^{\mathrm{ab}} \pm 0.40$ & $8.17^{\mathrm{a}} \pm 0.17$ & $7.83^{\mathrm{a}} \pm 0.31$ & $7.83^{\mathrm{ab}} \pm 0.40$ \\
\hline $\mathrm{T}_{3}$ & $1.25 \% \mathrm{NaCl}+0.35 \%$ STPP & $7.50^{\mathrm{ab}} \pm 0.22$ & $8.00^{\mathrm{ab}} \pm 0.26$ & $8.00^{\mathrm{ab}} \pm 0.00$ & $7.83^{\mathrm{a}} \pm 0.31$ & $7.83^{\mathrm{ab}} \pm 0.31$ \\
\hline $\mathrm{T}_{4}$ & $1 \% \mathrm{NaCl}+0.4 \% \mathrm{STPP}$ & $7.00^{\mathrm{bc}} \pm 0.00$ & $8.17^{\mathrm{a}} \pm 0.31$ & $8.33^{\mathrm{a}} \pm 0.21$ & $7.75^{\mathrm{a}} \pm 0.17$ & $8.17^{\mathrm{a}} \pm 0.31$ \\
\hline $\mathrm{T}_{5}$ & $0.75 \% \mathrm{NaCl}+0.45 \%$ STPP & $6.83^{\mathrm{dc}} \pm 0.17$ & $7.50^{\mathrm{ab}} \pm 0.34$ & $7.00^{c} \pm 0.00$ & $7.50^{\mathrm{ab}} \pm 0.22$ & $7.17^{b} \pm 0.17$ \\
\hline $\mathrm{T}_{6}$ & $0.5 \% \mathrm{NaCl}+0.5 \% \mathrm{STPP}$ & $6.33^{\mathrm{d}} \pm 0.33$ & $6.67^{b} \pm 0.49$ & $6.17^{\mathrm{d}} \pm 0.17$ & $6.50^{\mathrm{b}} \pm 0.81$ & $6.00^{c} \pm 0.00$ \\
\hline \multicolumn{2}{|r|}{ value } & $\leq .0001$ & 0.0007 & $\leq .0001$ & $\leq .0001$ & $\leq .0001$ \\
\hline
\end{tabular}

Different alphabets on means showing significant differences within a raw $(P \leq 0.05)$.

${ }^{1}$ Sodium chloride

${ }^{2}$ Sodium tripolyphosphate

${ }^{3}$ Standard error

Conclusion: Results from the present study revealed that use of $0.75 \% \mathrm{NaCl}+0.45 \%$ STPP improved tenderness which is the most important factor in judgement for quality of meat and meat products. In addition, the treatment with $1-1.25 \% \mathrm{NaCl}$ in combination with 0.35 $0.40 \%$ STPP improved cooking yields and were acceptable to the sensory panel. Therefore, it is concluded that relatively low concentration $(0.75-1.25 \%)$ of sodium chloride in combination with low concentration $(0.35-$ $0.45 \%$ ) of sodium tripolyphosphate may improve the quality of fresh vacuum tumbled poultry meat.

\section{REFERENCES}

Alvarado, C.Z. and S. McKee (2007). Marination to improve functional properties and safety of poultry meat. J Appl Poult Res. 16(1): 113-120.

Alvarado, C.Z. and AR. Sams (2004). Early postmortem injection and tumble marination effects on broiler breast meat tenderness. Poult Sci. 83(6): 1035-1038.

Bowker, B. and H. Zhuang (2017). Freezing-thawing and sub-sampling influence the marination performance of chicken breast meat. Poult Sci. 96(9): 3482-3488.

Carroll, C.D., C.Z. Alvarado, M.M. Brashears, L.D. Thompson and J. Boyce (2007). Marination of 
turkey breast fillets to control the growth of Listeria monocytogenes and improve meat quality in deli loaves. Poult Sci. 86(1): 150-155.

Desmond, E., (2006). Reducing salt: A challenge for the meat industry. Meat Sci. 74(1): 188-196.

Fernandez, L.J., B.E. Sayas, J.A. Perez-Alvarez and C.V. Aranda (2004). Effect of sodium chloride, sodium tripolyphosphate and $\mathrm{pH}$ on color properties of pork meat. Color Res Appl. 29(1): 67-74.

Froning, G.W. and B. Sackett (1985). Effect of salt and phosphates during tumbling of turkey breast muscle on meat characteristics. Poult Sci. 64(7): 1328-1333.

Gamage, H.G., R. Mutucumarana and M. Andrew (2017). Effect of marination method and holding time on physicochemical and sensory characteristics of broiler meat. J Agric Sci. 12(3): 172-184.

Gorsuch, V. and C.Z. Alvarado (2010). Postrigor tumble marination strategies for improving color and water-holding capacity in normal and pale broiler breast fillets. Poult Sci. 89(5): 10021008.

Kin, S., M. Wes Schilling, J.L. Silva, B.S. Smith, V. Jackson and T. Kim (2009). Effects of phosphate type on the quality of vacuumtumbled catfish fillets. J Aquat Food Prod Technol. 18(4): 400-415.

Komoltri, P. and P. Pakdeechanuan (2012). Effects of marinating ingredients on physicochemical, microstructural and sensory properties of golek chicken. Int Food Res J. 19(4): 1449-1455.

Latif, S.S. (2010). Effect of marination on the quality characteristics and microstructure of chicken breast meat cooked by different methods. Lucrari Stiintifice. 54: 314-324.

Li, C., L. Zhang, F. Ren, Z. Yao, H. Hu and X. Li (2012). Study on different chilling factors influencing water-holding capacity of pork based on lowfield nuclear magnetic resonance (LFNMR). Transactions of the Chinese Society of Agricultural Engineering. 28: 243-249.

Lopez, K., M.W. Schilling, T.W. Armstrong, B.S. Smith and A. Corzo (2012). Sodium chloride concentration affects yield, quality, and sensory acceptability of vacuum-tumbled marinated broiler breast fillets. Poult Sci. 91(5): 11861194.

Lorenzetti, E., J. Soares, H. Treichel, R.L. Cansian, C. Steffens and E. Valduga (2015). Brine absorption in seasoned chicken pieces. J Verbrauch Lebensm. 10(4): 331-340.

Long, N.H.B.S., R. Gal and F. Bunka (2011). Use of phosphates in meat products. Afr J Biontechnol. 10(86): 19874-19882.
Lyon, B.G., D.P. Smith and E.M. Savage (2005). Descriptive sensory analysis of broiler breast fillets marinated in phosphate, salt, and acid solutions. Poult Sci. 84(2): 345-349.

Makiaa, and G.W. Froning (1987). Effect on the quality characteristics of turkey breast muscle of tumbling whole carcasses in the presence of salt and phosphate. Poult Sci. 66(7): 1180-1183.

Mudalal, S., M. Petracci, S. Tappi, P. Rocculi and C. Cavani (2014). Comparison between the quality traits of phosphate and bicarbonate-marinated chicken breast fillets cooked under different heat treatments. Food Nutr Sci. 5(01): 35-44.

Parks, S.S., A.E. Reynolds and L.Wicker (2000). Aqueous apple flavoring in breast muscle has physical, chemical, and sensory properties similar to those of phosphate-marinated controls. Poult Sci.79(8): 1183-8.

Puolanne, E.J., M.H. Ruusunen and J.I. Vainionpaa (2001). Combined effects of $\mathrm{NaCl}$ and raw meat $\mathrm{pH}$ on water-holding in cooked sausage with and without added phosphate. Meat Sci. 58(1): 1-7.

Ruusunen, M. and E. Puolanne (2005). Reducing sodium intake from meat products. Meat Sci. 70(3): 531-541.

Saha, A., Y. Lee, J.F. Meullenet and C.M Owens (2009). Consumer acceptance of broiler breast fillets marinated with varying levels of salt. Poult Sci. 88(2): 415-423.

Sheard, P.R., and A. Tali (2004). Injection of salt, tripolyphosphate and bicarbonate marinade solutions to improve the yield and tenderness of cooked pork loin. Meat Sci. 68(2): 305-311.

Smith, D.P. and L.L. Young (2007). Marination pressure and phosphate effects on broiler breast fillet yield, tenderness, and color. Poult Sci. 86(12): 2666-2670.

Smith, DP. and J.C. Acton (2001). Poultry meat processing. $2^{\text {nd }}$ edition. Florida(USA). 257-281 p.

Woelfel, R.L. and A.R. Sams (2001). Marination performance of pale broiler breast meat. Poult Sci. 80(10): 1519-1522.

World Health Organisation. 2016. Salt reduction. [cited 2017 Nov 08]. Available from: http:/www.who.int/mediacentre/factsheets/fs39 3/en/

Young, O.A., S.X. Zhang, M.M. Farouk and C. Podmore (2005). Effects of $\mathrm{pH}$ adjustment with phosphates on attributes and functionalities of normal and high $\mathrm{pH}$ beef. Meat Sci. 70(1): 133139.

Yusop, S.M., M.G. O’Sullivan, J.F. Kerry and J.P. Kerry (2010). Effect of marinating time and low $\mathrm{pH}$ on marinade performance and sensory acceptability of poultry meat. Meat Sci. 85(4): 657-663. 